\title{
Becoming Unsettled Again and Again: Thinking With/in and Against Autobiographical Writing
}

\author{
Audrey Aamodt
}

University of Regina

\begin{abstract}
This theoretical paper takes up pieces of the process of thinking about, and proposing, my $\mathrm{PhD}$ research in the context of (my own) treaty personhood identities. Demonstrating tension through autobiographical writing, I aim to disrupt humanist notions of (my) self as stable, rational, and understandable. With some attention to certain poststructural philosophies, especially by engaging in Deleuzian lines of flight, I seek to continually unsettle the assumption that (my) self can be known fully, that (my) subjectivity can easily be named. Instead, I view identities as plural and shifting, and subjectivity as a process of identity formation that is socially constructed. As well, the process of writing such self-stories further constitutes (my) self, in a relational process with other texts and contexts, towards becoming-otherwise again and again.
\end{abstract}

Keywords: Deleuze; lines of flight; subjectivity; identity; self-stories; life-writing; autobiography; poststructuralism

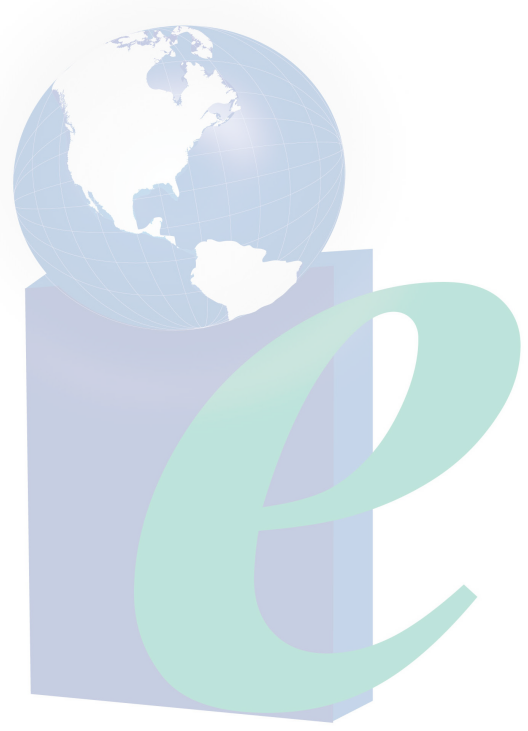




\section{Becoming Unsettled Again and Again:Thinking With/in and Against Autobiographical Writing}

\section{Tell Me About Yourself}

Since the theme of this special issue of in education is power and identity, it seems worthwhile to begin by sharing my intention in submitting this piece, and how it aligns with this theme. Throughout the following, purposefully winding, theoretical discussion, I play with notions of the self, and more specifically, my self. Using various self-stories, I perhaps not-so-subtly hint that identity is less coherent than certain normative, humanist tendencies would have us believe. Yet, it is easy to become consumed with efforts to know oneself and, thereby, possess whatever power that knowing might afford. For instance, recall the last time you ${ }^{[1]}$ (the reader) met someone new. Perhaps you shook hands and chatted a little, trying to get a sense of who they are as well as demonstrate something about yourself. Maybe some sort of statement such as "tell me about yourself" passed through lips, with an assumption that this would help. What story do you tell? Do you mention your job, your interests and hobbies, your relationships to others?

Who am I? How do I want to represent myself? Can I choose who I am? Can I understand myself? When I hear myself say to someone, "it's nice to meet you," how much can I really know about them and offer in return? What if knowing oneself in full is impossible? While it could be argued that introductions are helpful, I draw upon poststructural theory to contend that the self is also a social construction. Therefore, maybe you think it might be useful to know about who I am, what I do, and how my particular perspective shapes what I offer next. It might give you comfort if I share certain introductory details (such as, that I am a doctoral candidate who calls Saskatchewan her home, whose European grandparents homesteaded here around a hundred years ago) to situate my writing below. However, it seems important to ask what such self-defining techniques allow and constrain. What if I refrained from telling you so straightforwardly exactly who I think I am? Instead, I invite a partialness to self-stories in order to illustrate that identity can be conceptualized as much more complicated than knowing myself in full and coming to know you. In these storied ways, the idea of identity can be opened up as a complex, shifting, and constitutive process.

\section{In the Middle of Things: A Contextual Note}

With the idea of identity as a process in mind, I would like to highlight my playful intentions with Deleuzian, poststructural, lines of flight. I attempt to let my writing take me/us where it will, with openness to how self-writing further constitutes the self. I use text boxes to interrupt the ways in which I sometimes feel obligated to engage in academic work, as well as to welcome these authors into the conversation, indulging in their thoughtful theory towards teasing me/us into thinking and becoming otherwise. Much of what follows was written in the context of proposing my $\mathrm{PhD}$ research, with attention to (my own) treaty personhood identities. Therefore, in this middle-of-things-beginning, I will make one small preamble note about this.

Canada has a relatively recent colonial history with continued legacies of oppression of Indigenous peoples, including racism and violence. Furthermore, relationships between settler and Indigenous people in Canada often suffer from misunderstanding and resentment. My family history, and my life, on the Canadian prairies was and is made possible by the signing of the Numbered Treaties between the Crown and various First Nations to open up areas for settlement, agriculture, and more (Office of the Treaty Commissioner, 2006). Although treaties were meant 
to be mutually beneficial, as an agreement to be in ethical relationship with one another and this land, there is a common misconception on the prairies, and perhaps more broadly, that treaties only affect Indigenous communities, and that treaty people are only First Nations people. This normative narrative seeks to plant people with pioneer family history as the "right kind" of Canadian. However, those with settler ancestry, myself included, also continually benefit from treaties.

Therefore, I find it important to ask: What does it mean to be a treaty person? As well, in what ways do I understand myself as a treaty person? I would argue that these questions go beyond intellectually adopting treaty person as another self identifier, to simply list alongside those other, too often viewed as static, positionalities, such as daughter, sister, farm girl, and even with attention to my racialized whiteness, my able body, and my straight sexuality. Thus, I look to self-stories and writing-the-self to interrogate the trickiness of this identity work, in a process of identity making and unmaking.

\section{Death of the Daffodils: Resisting Linearity Through Writing-Stories}

The daffodils are dying on my desk-Their leaf tips yellowing and petals wrinkling in the vase before they had even fully bloomed. It is almost as if they know that it is too early for daffodils here. After all, it is still only early March in Southern Saskatchewan, with plenty of full, fluffy snowfall this past week. Yet, as I contemplate their hasty death, it seems I had wished that the simple act of purchasing them would be enough to bring in spring or, at least, ease my anxious mood. Perhaps I should know better, I think, for, how could greenhouse daffodils, assigned to my desk, be expected to raise the temperature or my temperament?

Laurel Richardson (2002) makes use of what she calls "pleated text" folded between "writing stories-about the contexts in which [she] wrote... The pleats can be spread open at any point, folded back, unfurled.” (p. 40). She has "accepted writing as process of discovery, and writing autobiographically as a feminist-sociological praxis... structured rhizomatically, the way [her] life is experienced-lines of flight, whirling whirling skirts of pleated texts. A surpisingly surprising de-disciplined life” (p. 50). Winter will last as long as it will and spring will come; they always do. However, I suspect my anxiousness will not abate as quickly, if ever, and it follows me into my writing and my thinking, that is, my thinking through writing (St. Pierre, 2005, p.967). Perhaps the death of the daffodils is a shadow of my hesitation to share these writing-stories as “knowing in being” (Barad, as cited in Jackson \& Mazzei, 2012, p. 116). My fear hints that, like the daffodils, it is too early and I am not ready. Even as I try to, instead, use their death as a metaphor for beginning to let go, again, of who I think I am or once thought I was, to make an opening for becoming otherwise (as Foucault might say), the discomfort remains and intensifies.

"The project for post-critical, post- realist thought, Foucault argues, is to make it possible to think differently, and thus to open the possibility for acting differently, by making the present unthinkable.

... The author of such writing potentially changes the very terms through which identity is established, not in a prefigured, but in an emergent fashion. ... [with] transformative potential for both writer and reader, in an experiment with excess_-moving beyond what is already known and understood.” (Davies, 2014, p. 447).

Trying to tell myself that such uncomfortable feelings are promising, and correspond to what I feel compelled to write, I find a kind of encouragement in Boler's (1999) words: “An 
ethical aim of a pedagogy of discomfort is willingly to inhabit a more ambiguous and flexible sense of self" (p. 176). She asserts, "learning to see differently

"I believe this deconstructive work honors the ethical charge I have set for myself of trying to think differently, of trying to free myself of my self" (St. Pierre, 1997, p. 412). requires a willingness to live with new fears-what I call learning to inhabit a morally ambiguous self” (p. 182). Though, I wonder how I might become "more ambiguous" and what it might be like to embody a pedagogy of discomfort? I suppose, in other words, I am curious about subjectivity as conceptualized in a poststructural way, that is, subjectivity as socially constituted and continually in flux. Therefore, if identity is more complicated than stable categories, if the idea of self-as-fixed can be questioned, then I wonder how becoming unsettled might implicate pedagogy and education?

Specifically, I wonder about two subject positions, as they might relate to each other and place. Nevertheless, at the moment, I choose to resist listing or attempting to explain my specific interest in such particular positionalities. Instad, I invite some discomfort, towards suspending the categories, as I begin to problematize through autobiographical pieces rather than by an ordered inventory. However, not just yet.

"The writer is open to the experiment of writing in which the world is not reduced to what is known already, but pushes out into other ways of knowing, into the tangled possibilities of intersecting, colliding (Badiou, 2001) ... the [research writing] is part of the author's autobiographical trajectory. The focal point of interest is not the author's life, but the insights into the multiple intersections and possibilities it opens up” (Varella, 1999 as cited in Davies, 2014)

Writing the/my self seems far from straightforward. Straightforward. I can hardly believe that word came onto the page. The writing path, along with (my) research path, is not a straight road like those ones I am so used to driving down in the prairies. "As far as the eye can see." But

"Because it has given up on intentions, it cannot see very far down the road. It stalls, gets stuck, thumbs its nose at order, goes someplace the author did not know existed ahead of time, stumbles over its sense, spins around its middle in some overloaded imbrication that flies out of control into a place of no return”(St. Pierre, 1997, p. 414). foregoing ends, wraps idea around idea

can I see? Can I know (my)self? Perhaps I/it does not even always move in a strictly forward motion, so why did I assume that this exploration of identity should be straightforward? It seems quite ironic that I had even (unconsciously?) considered the possibility of writing this piece in a linear fashion. It was a thought buried down, underneath all of my hopes for creativity, for personal connection, for meaningful writing. Somehow though, I have attached myself in some ways to poststructural openness; I am stuck where I began. Stuck in structure. This writing process, these letters and words written one after another, makes it obvious to me. I gradually fall into patterns of straightforwardness. Completing one word, one sentence, one paragraph, determined the direction of the next word, sentence, paragraph, so much so that I became/become entrenched in having the words form a structure that I may not have intended or wished to communicate. Then, I remember. It is useful to fly out of control. Can I get free of (my)self? Will I risk living with the fear of becoming otherwise in that place of no return? To move into my own impossibility? I am having trouble with this
"Use writing as a method of inquiry to move into your own impossibility, where anything might happen—and will” (St. Pierre, 2005, p. 973). 
writing, this thinking, as I notice a desire to interrupt linearity while feeling the pull to "get it right”: the tension to be/come a certain kind of scholar for a certain kind of objective. I tried to stand apart from this writing, even though it came from me, is me. I stepped away. I left it alone. I did not know what to do next. Next. Next. Next. Always next. One thing comes after another in written pages, in thoughts, in words, in being, in time. Or does it? Does it have to? Does it need to? Does it "make sense" to?

I had the notion that I must, or could, convince you (and perhaps even myself) that these writing-stories might "count” as research, as scholarship, that it might be "legitimate.” Yet, I notice that this desire seems rooted in a positivist tradition. Also, if it was linear, and straightforward enough, it might be more believable, more "real," more rational, more worthwhile. Yet, this is exactly what I attempt to disrupt. My thought(s), and (my)self, are not straightforward. They are (and I am) mangled in a mess, which is not necessarily something that needs to be fixed, I think. Try as I might to make sense of them and of my self, they/I refuse to be written sensically.

I have obsessed and continue to fixate on getting it right, that is, doing, proposing, and writing research correctly. I think I am ready to stop caring if it is "right"-whatever that might mean or imply. Perhaps I can let go of the thought that this writing needs to make sense (in a rational way), be linear, and written straightforwardly. What a linear thought. Yet, what might happen to my research, to my writing, to (my)self, if I attempt to espouse St. Pierre's (2005) approach to writing-inquiry, in that she has "developed a certain writerly incompetence and underachievement... unable to write a text that 'runs to meet the reader' ... a comfort text... that gratifies the interpretive entitlement to know” (p. 971). Being incompetent is interesting to me, much more so than being straightforward, much, much more so than knowing that I have got it right. So, here I/we go.

\section{I am a Canadian. I am a Prairie Girl. I am... a Treaty Person?}

The south Saskatchewan, Canadian prairie is the place I call home. To belong on the prairie is my desire. It has constituted (maybe even all of) my various and varying subjectivity, and continues to. I am from here, grew up here, still live here. This is all "true," I suppose. Yet, as I write these words, I simultaneously hear the entitlement I assume, a sense that perhaps follows me in blood but at least in

"I am a prairie girl. Visions of flat land as far as my eye can see run through my mind when I remember growing up in Saskatchewan. To me, childhood is synonymous with concepts of the farm, open countryside, and limitless sky” (Aamodt, July, journal, 2008). history. My European great-grandparents took
"I am a prairie girl, or so I have called myself in my mind or aloud many times before... I embraced the Saskatchewan prairies as my home, without question, as I always had... I was a prairie-girl and always would be" (Aamodt, journal, November, 2013).

up homestead settlements on the southern Saskatchewan prairies in the early part of the 20th century, and my family has been tying our identity to these parcels of land ever since. Although, of course, celebrating our family's homestead centennials is relatively ridiculous, and seems to be another colonizing act, an addition to the settler story of taming a vast, harsh, people-less land. I live in town now, but I wonder if I have ever left the farm. Could I ever leave? 
In my autobiographical writing, it seems quite apparent that I continue to take up a settler subjectivity. Furthermore, I have begun to understand (my) autobiographical writing as discourse; something beyond narcissistic or indulgent self-story telling; a discursive practice of (re)making the self. Such writing bursts with clues to grand narratives (perhaps a way to hunt them down), and to how subjectivities are (socially, and perhaps ecologically) constructed. For example, in an undergraduate curriculum course that I have previously helped to facilitate, student teachers are asked to write autobiographically about the people, places, and spaces that they think have shaped them to want to become teachers. More interestingly, later, we then asked that they look for what is absent from their stories, what is missing, and why. This is a difficult task. Many express how confronted they feel by being

"Treaties are an important part of history as they enabled the settlement of vast tracts of land, establishing the foundation for the growth and development of the Canadian west” (Tupper \& Cappello, 2008, p. 559). challenged to consider how their stories might reflect dominant discourses. They want their personal stories to be simply that, personal and non-implicated. I do too, but it is not so. My settler identity is entangled in national narratives, the building of Canada as a nation, and common sense notions of who is considered a "true" Canadian. Therefore, the numbered Treaties were not part of my understanding of being on our settled land.

Treaties? What is a treaty? When did I first learn of these agreements to "share the land"? How was it explained? I do not recall... Was it ever? I do remember seeing a poster once, in the staffroom of the high school I was teaching at, years ago. I think it might have been an advertisement for a Treaty Education workshop for teachers, though I cannot say if this is exactly what it was. It seemed interesting, but how could I make the case to attend? I taught math and biology; it did not seem applicable to me then. I quickly dismissed it in a "that kind of thing is only for social studies teachers” way.

Recalling this, I watched and listened as some student teachers, those same students we

"Listen up! This is important!... We are all treaty people... You don't need a status card to be a treaty person... We are all treaty people... because we are Canadian, we signed treaties...it's a sharing of the land... why didn't I know this?...

Saskatchewan has mandated treaty education in $\mathrm{K}$ to Grade 12, in all classes... learning about treaties means understanding each other... learning about treaties is the first step to getting rid of racism... we are sharing the land... it's more than history, it's today... we are all treaty people, now you know, so what are you going to do about it? All Canadians are treaty people” (Horizon School Division \#205). asked to write autobiographical stories, were shown a Treaty Education video published by a Saskatchewan school division. I wonder about what this call to "Listen up!” does to the way student teachers think of themselves. Afterwards, are they able to shrug, and say, "Okay, I guess I am a treaty person"? Maybe they already identified as such, though, through discussing this with them in class, and reading their required autobiography assignments, I suspect this is highly unlikely and probably much more complicated. However, now they "know" that, to be a good student teacher, and maybe even a good Canadian, they should identify as a treaty person if they live on treaty territory, no matter their race, heritage, ethnicity, or family history. I wondered, if saying so (once or many times), or writing it or thinking it, might allow them (and me) to take up a treaty person subjectivity? I have lived on Treaty Six and Four land for my entire life, and although I am "well-educated," I think I have only begun to question what it might mean to be a 
treaty person.

Here, I feel a Deleuzian "pause in the middle of things" (Gough, 2009, p. 79), to elaborate on meaning, would be helpful. So far, now and then, I have alluded to questioning the meaning of things - what it would be like to embody a pedagogy of discomfort; if non-linear research could mean something worthwhile or be meaningful; what being a treaty person might mean. I have a habit of implying phenomenological questioning, onto-epistemically (invoking being meaningful and meaningful being) — that is, related to lived experience and a search for meaning in the interpretive tradition. During my master's thesis, by using phenomenology as a research methodology, I felt as though I was beginning to be constructed as an (environmental) educational researcher, and formed an affinity to phrasing questions in such phenomenological ways. I wanted such interpretive work to assist me in an acknowledgement of things that might be often taken for granted. I looked for meaning in lived experiences, without recognizing the tangled subjectivities of the people who make these meanings. I assumed there was meaning "out there" to be understood. Yet, perhaps, if I think of it with a poststructural slant, meaning (and identity) is not found but

"Postmodernists, after the linguistic turn, suspect that interpretation is not the discovery of meaning in the world but rather the 'introduction of meaning' ", (St. Pierre, 2005, p. 968).

"To risk meaning nothing is to start to play" (Derrida, as cited in St. Pierre, 2005, p. 969) (re)produced, it is made and remade. So, instead, I hope to re-“imagin[e] writing as a letting go of meaning, even meaning [which] proliferates rather than a search for and containment of meaning” (St. Pierre, 2005, p. 969).

"Exploring uses of autobiography that address and even exemplify performativity, the power of discourse to produce, through reiteration, an "I" that is always coming into being through social and cultural constructions of... identity and, simultaneously, failing to cohere” (Miller, 2005, p. 219).

So, calling myself a treaty person likely means more than it simply seems through being signified as such-especially as a White-settler treaty person whose family might give her confused looks if she asked them about treaties, or if they could call themselves treaty people. Likewise, I have asked those student teachers how it is that none of them referred to treaties within their autobiographies, asking them to question if they would call themselves treaty people now that they know that they will be required to teach Treaty Education to their Saskatchewan students. The most vocal said "not really," or a polite "maybe," at best. Perhaps they did not write about it in these autobiographical pieces because it was not perceived as relevant to their desire to become a teacher. Would they think it relevant if I asked a different question? Would they speak of treaties if land were part of a prompt? Is a treaty person subjectivity constituted by knowledge of the history of (Canadian) land? Why and how might this be so? What about our relation to that land and our relations with each other? Perhaps coming to know/see/understand a subjectivity process is stickier and trickier than simply stating particular identity labels, such as "treaty person". I wonder more about becoming unsettled to think so, and taking up a settler subjectivity as an unsettling of the settler self.

\section{Unsettling the Settler/Settled Self}

To play with meaning and identity as tenuous, I wish to use the word unsettled for various purposes. In one way, it might mean contesting that subjectivity is akin to fixed 
identity/identities. It might elicit a confrontation of feelings and a questioning of being and becoming, personally and scholarly. In another way, related to treaty relationships, it might also be used to imply a plea for decolonization. Regan’s (2010) book, Unsettling the Settler Within, stresses that non-Indigenous Canadians should attempt to become decolonized, perhaps by becoming unsettled in both epistemological and ontological ways. Even so, it is important to stress that “decolonization is not a metaphor” (Tuck \& Yang, 2012).

During a course, entitled Introduction to Postcolonial Theories and Representations, one guest speaker introduced herself as a White, woman, settler. These identity signifiers surprised me and I wondered if this was how I should also introduce myself, if that was the scholarly thing, and/or the politically correct thing, to do. Later, a classmate wrote (White, settler, invader) after her name on one of her shared pieces. In a different context, nearly a year after this experience, I heard someone else begin her talk with, "I am a White, woman, settler, unsettled." "Living as a settler-invader [emphasis added] subject in Canada implies implication, for our homes, our wealth, our existence here are predicated on a long history of dispossession (Newbery, 2012, p. 41). That is, "settler-invader educators and students are implicated in this history by our very presence on Aboriginal lands” (p. 39). Naming oneself as settler-invader, becoming-unsettled is... unsettling. It makes me want to play around with what to call myself, how to name my subjectivities (as if subjectivity is a noun, rather than a verb), how to discursively articulate my self in particular moments. Also, I wonder about how this/I might inadvertently re-center dominance, and if it could be avoided (I fear not). Could such questioning be, partly, decolonizing work? Or, is it simply another "settler move to innocence” (Tuck \& Yang, 2012, p. 9)? Does it “only serve the settler” (p.10)?

Yet, as I identify my settler ancestry and, therefore, call myself settler, it seems as though a certain philosophical subjectivity - the part of myself that could become a "philosopher of education [who] might foster more ethical relations to Indigenous intellectual traditions and thus begin a process which seeks to de-colonize knowledge production” (Richardson, 2012, p. 673)_might be "erased" through signifying myself as settler. Bingham (2008) hints at how Derrida may help to explain such erasure in this context. The term settler could be said to signify particular things, through Derrida's concept of différance, potentially deferring the meaning related to a person to particular acts of colonialism, even as each settler would differ from one another in their particular contexts. The settler (signifier) is in relation to colonialism (signified) and perhaps gives way to this context. In this way, it seems as though (my) settler subjectivity becomes unable to become decolonized or engage in decolonization, since a settler is a colonizer (Veracini, 2011; Tuck \& Yang, 2012). That is, the settler is “called upon to erase him or herself” (Bingham, 2008, p. 18), perhaps to erase the potential for a "re-making of self from the point of view of the word....arrived at through a circling of the abyss” (Richardson, 2012, p. 671).

However, I think Bingham's use of Derrida's concept of erasure is perhaps a bit different than I have read elsewhere, related to the notion of a poststructural deconstruction as putting something “under erasure” (MacLure, 2011; St. Pierre, 2004a). Therefore, perhaps what becomes necessary is putting my settler self under erasure thereby putting a strikethrough myself as settler. Instead, I might call myself a settler to denote the (im)possibility of what that subjectivity implies, that is, "in the acknowledgment that it is one of those impossible things that [I] cannot do without” (MacLure, 2011, p. 288). Therefore, perhaps my identity as a settler need not be conceptualized as fixed in such a way that I am unable to continue to become a philosopher who works towards decolonization (of the self) by ethically engaging with Indigenous ways of 
knowing (since a fixed settler identity might imply/assume an inability to do so ethically or equitably, in trepidation of appropriating Indigeneity and furthering colonialism).

Perhaps, through deconstruction, this kind of philosopher-subjectivity is what becomes noticeable as absent in the presence of settler. A deconstruction of subjectivities might be like attempting to feel what is absent, and therefore present in their absence. Norris (as cited in West, 2010) describes deconstruction as "the vigilant seeking-out of those 'aporias', blindspots or moments of self-contradiction” (p. 204). Perhaps Derrida's “endless dispersion and multiplication of meanings," which "undermines all fixities of interpretation, proliferates rather than reduces instances of ambiguity” (West, 2010, pp. 204-205) may also help to conceptualize an engagement with subjectivity as a process rather than a thing contained or defined. "This is indeed the freedom of a subject constituted, not in advance of the world, but in material and discursive relations that always offer the possibility of transformation” (St. Pierre, 2004a, p. 326).

(My)self as settler “comes undone” (Bingham, 2008, p. 27) by an attempt at putting these subjectivities under erasure, and simultaneously "one must not pretend to erase oneself" (Bingham, 2008, p. 30). Therefore, I cannot erase myself as settler; yet, the notion of settler may be put under erasure so that a more complicated settler subjectivity may continue to be constituted. Autobiographical writing activities make room to explore such subjectivity as process, as a deconstruction, towards a decolonization of the self-in-relation, towards settlerbecoming-unsettled.

For, "advancing social justice in settler society [is a] component in the process of "Enact ethical relationality as a
philosophical commitment. Ethical
relationality is an ecological
understanding of human relationality that
does not deny difference, but rather seeks
to understand more deeply how our
different histories and experiences
position us in relation to each other"
(Donald, 2012, p. 535).
"Encourage negotiated understandings of
the world, engage with divergent sources
of knowledge, and to stress a reflexive
awareness of limitations and fallibility of
the 'Self' as part of a larger project to
oppose social oppression” (Montgomery,
2013, p. 15). decolonization" (Episkenew, 2009, p. 15). Perhaps decolonization, in the form of becoming unsettled, implies an "ethical relationality" (Donald, 2012, p. 535). In this context, there are "compelling arguments for the necessity of discomforting privileged students and, especially, for utilizing an engagement with any discomfort" (Montgomery, 2013, p. 16). That is, privileged students should not be "spared from unsettling knowledge" (p. 16). In what ways might knowledge be unsettling? How could encountering unsettling knowledge also make possible an unsettling of one's being, or rather, one's becoming-unsettled?

Differently, yet with similarities, Todd (2007) uses the works of Arendt, Lyotard, and Levinas to write about justice and education, concluding that "the real potential of human rights education lies in its capacity to provoke insights that help youth live with ambiguity" (p. 592). I suspect a multitude of philosophies could be put to use when calling for an ambiguous sense of self, though, in this moment, I resist proposing a particular angle. Perhaps keeping an opening will allow for the unsettling to deepen and will make lines of flight possible. St. Pierre (2004b) makes reference to lines of flight as a Deleuzian concept or figuration. Hopefully, such openness might also make room for a questioning of my fondest attachments. St. Pierre (2004a), citing Butler, compels us to ask "Why it is we come to 
occupy and defend the territory that we do, what it promises us, [and] from what it promises to protect us?” (p. 327). St. Pierre suggests, “[this] is the ethical question we must inevitably ask of our fondest attachments” (p. 327).

Here, I am reminded of a small, somewhat obscure comment, from Critchley (1997), that makes me wonder more about "a critical dismantling of the [continental philosophy] tradition in terms of what has been unthought within it and what remains to be thought” (p. 355). I have in some ways become attached to what the yet unthought might offer towards becoming unsettled, and I want to couple this with humility. As Montgomery (2013) writes, "to practice humility as a critical pedagogue is to... vigilantly remind oneself that not 'everything important lies in our awareness"” (p. 15). Bringing “critical pedagogue” as a subjectivity into the mix of unsettled subjectivities makes this all feel even more complex, and more unsettling. Perhaps this hints to another line of flight towards becoming unsettled again and again.

\section{Unsettling Autobiography: With/in and Against Self-Stories}

\begin{abstract}
"So you will never get to the bottom of a concept like [nonthought within thought], you will never be able to figure out what it really means, nor, if you become the least bit Deleuzian, will you want to. Rather than asking what a concept means, you will find yourself asking, "Does it work? what new thoughts does it make possible to think? What new emotions does it make possible to feel? What new sensations does it open in the body?” (St. Pierre, 2004b, p. 284).
\end{abstract}

St. Pierre's (2004b) use of Deleuze and Guatarri helps me think about the possibility for the unthought in another way. She says, "what is exciting for those who plug a Deleuzian machine into another machine is that different assemblages become possible that could make available the 'nonthought within thought'... that some of us long for" (p. 284). I am quite sure that I do not understand what this means, but I do long for it, and I am reassured that trying to use the concept(s) is the more important aspect of such a philosophy.
Letting go of meaning, I let the concept work. Then, the I is an assemblage. Writing assemblages create the possibility for making available the nonthought within thought, for refusing to repeat this self, this I that I thought/think I know. Conceptualize subjectivity as an assemblage, a relational assemblage, an ethical assemblage.

Fearing that these written pages, this disruption of (my) humanist self, could be considered quite muddy, and worse yet, that it is quite linear in composition-quite stable, rational, understandable-I recall that the purpose of this piece is to partially speak to how subjectivities are constituted, lived, and articulated. Also, as Chapman (2005) ponders, regarding the writing up of research, "maybe we don't have to give them a blow-by-blow account of how we wrote the story, researched it, analyzed it and then regurgitated it, complete with 'implications for practice”' (p. 261). Maybe the same might hold for a research proposal, or a theoretical paper. To me, risking it seems necessary.

In this always-in-the-middle-of-things moment, for (un)clarity, I include a few thoughts related to how subjectivity as assemblage is currently playing out in my own $\mathrm{PhD}$ research (http://www.becoming-unsettled.org). I seek to intentionally (mis)use autobiographical writing to expose certain unthoughts, or to make room for that which has yet to be thought about (my)self, 
to become unsettled again and again. However, I also wish to problematize the use of autobiography as research method. In Miller’s (2005) words,

What might happen in educational theory and practice if we were to use autobiography to "trouble" the links between acts, categories, representations, desires and identities? What possibilities might open if we were to make evident identity's construction in order to create more space for and recognition of the various actions and "selves" performed daily in a social landscape often blinded and hostile to variety? (p. 219)

As a relational assemblage, I explore various im/possibilities that autobiographical métissage, as a philosophical research praxis, offers. Using métissage as pedagogical/research sensibility, Hasebe-Ludt, Chambers, and Leggo (2009) braid their respective, curricular, autobiographical writings in provocative ways, which attempt to speak within/against normative narratives. Donald (2009) explains this as,

rather than viewing métissage as a solitary research

Hasebe-Ludt et al. (2009) "take métissage as a counternarrative to the grand narratives of our times, a site for writing and surviving in the interval between different cultures and languages, particularly in colonial contexts" (p. 9). and textual praxis, this form of métissage relies on collaboration and collective authorship as a strategy for exemplifying, as research practice and text, the transcultural, interdisciplinary, and shared nature of experience and memory. (p. 9)

However, he argues for a different kind of métissage, one that is more explicit about the possibility for decolonization, that is "métissage [as] a way to reconceptualize and decolonize culture and historical consciousness in the context of teaching and learning today" (Donald, 2012, p. 538). He stresses the ethical relationality involved in such praxis, calling the research sensibility Indigenous métissage and envisioning that it "purposefully juxtaposes layered understandings and interpretations of places in Canada with the specific intent of holding differing interpretations in tension without the need to resolve or assimilate them" (Donald, 2012, p. 542). More specifically,

Indigenous Métissage is focused on interpreting and reframing the historical and contemporary interactions of Aboriginal peoples and Canadians... informed by Indigenous philosophies, ethics, and ways of knowing... [but] does not connote an exclusionary type of métissage done for, by and with Aboriginal people only... this type of inquiry must be interpreted in a Canadian context. In that sense, [the interactions] are specific in origin or indigenous to Canada; they could not happen elsewhere. (Donald, 2009, p. 10)

Both literary and Indigenous métissage use place as a backdrop, though Donald also mentions

"And since writing is always situated in a place, and since the place of writing always motivates and informs and constrains the writing, it is important to grow more aware of the places where writing is situated" (Hasebe-Ludt, et al., 2009, p. 98). his subject position as of Aboriginal and European decent, and is, therefore, somewhat more able to hold both colonial and Indigenous storied perspectives. He stresses the importance of invoking place-stories of difference, with artifacts storied in contention. Therefore, he warns about the dangers of subsuming métissage in postcolonial theories of hybridity, instead emphasizing métissage for expressing difference, towards being in tension for facilitating decolonization. What might this mean for a 
"White, woman, settler, becoming unsettled”?

I apply Jackson and Mazzei’s (2012) thinking with theory as a way to explore métissage differently. Lewis (2012) seems to call something similar "constellational thinking” (p. 99), holding theories in an imaginary constellation, though Jackson and Mazzei (2012) have situated their work by using Deleuzian concepts of plugging in, folding, being in a threshold, and entering an assemblage. Their work encourages me to pursue lines of flight, whatever those may be.

"Perhaps all of life is really lived in thresholds, in states of liminality... Métissage honors the places of liminality, of in-betweenness, of relationship, and therefore supports autobiographers to investigate storied lives as fecund with possibilities, as wholly connected to the stories of others" (Hasebe-Ludt et al., 2009, p. 99).
"This researcher, was not the unified, contained, stable individual of liberal humanism but a subject folded into subjectivity by the outside... always part of it, folding unfolding, refolding with/in it” (St. Pierre, 1997, p. 411). edge of autobiography (at the edge of self?), and at the edge of Métissage, shouting through it and back to it, shouting back to my self?

Might a writing-thinking-Metissage-with/in-theory work to unsettle (my) self? Perhaps Miller (2005) might refer to this becoming-unsettled, becoming-Métissage, as engaging in queering autobiography:

An educator who conceives of autobiography as queer curriculum practice doesn't look into the mirror of self-reflection and see a reinscription of her already familiar, identifiable self. She finds herself not mirrored-but in difference... In the space she explores between self and other, nothing looks familiar; everything looks a little unnatural. (p. 224)

This inquiry is about (my/our) enactment in the process of becoming unsettled as a (poststructural) researcher, this student-scholar subjectivity. It is not just about me, though it is about using myself as a site to explore subjectivity, perhaps including what it means to become reflexive with ethical relationality. I also take up Pillow's (2003) words:

A reflexivity that pushes toward an unfamiliar, towards the uncomfortable, cannot be a simple story of subjects, subjectivity, and transcendence or self indulgent tellings. A tracing of the problematics of reflexivity calls for a positioning of reflexivity not as clarity, honesty, or humility, but as
"In the process of this writing, I began to turn my reflexive gaze on the words written on the page, as they turned their gaze on me, and the ways theory and practice looped with and around the writing. I came to see that writing 'reflexively' is not about including the 'me' in writing, although this is important. It is also about the play between theory and practice, words and ideas, writing and thinking, thinking and doing” (Laws, 2004, p. 123). 
practices of confounding disruptions - at times even a failure of our language and practices. (p. 192)

\section{A Pause, in the Middle of Things: Again and Again}

Stronach (2011) writes that "casting around in ignorance, confusion, (and even despair!) is very much the process of coming-to-think" (p. 308). As I engage in thinking about subjectivity research, this strikes me as an(other) awful thought, for why would anyone want to live in ambiguous discomfort, uncertainty, or even despair - that is, to become unsettled - only for the sake of thinking differently than I have previously, or presently do? Yet, these in-between moments are when I feel terribly excited about the possibilities for research, for education towards decolonization and reconciliation. Those moments when,

awful thoughts erupt. They can remind us of our reluctance to think, our susceptibility to acting them out or projecting them onto others, and maybe even our willingness to become distracted by technical consolations and functional understandings... the having of awful thoughts is necessary. They can break us out of the numbing routine... our thoughts can question their own grounds and then wonder over the relation and difference between thoughts and things. (Britzman \& Dippo, 2000, p. 34)

Therefore, I will continue to attempt to pluck up enough courage to "be willing to risk thinking again and again” (Britzman \& Dippo, 2000, p. 34). Perhaps possibilities for contributing to creating a more ethical self and world lie in the process.

\section{Autobiographical Counter-Stories (in Time)}

The above reflection gives me pause, once again in the middle of things, to resituate myself in this writing work. Perhaps it could be considered another writing-story, as Richardson (2002) might call it: another that helps to complicate my desire for exploring subjectivity, specifically the ecological with the treaty, related to place. Such autobiographical writing may lend itself to an exploration of (my) subjectivity, not as a repetition of (my)self, but as a possibility for opening up (my) subjectivities to reconfiguration, perhaps enabling "tiny explosions of the self that refuse to repeat the same 'I'” (St.

Thompson and Cook (2013) discuss the notion of repetition through Deleuze, who "celebrates the bad copy, the simulacrum, as a repetition that establishes the futility and the perversity of attempts to copy models as repetition... forc[ing] us to confront the tragedy of the attempt to repeat the same (p. 252); "For Deleuze it is a celebration of the centrality of difference and the peripheral nature of sameness or identity. If we cannot repeat precisely, as Deleuze insists, then we may well celebrate the falling away” (p. 251).
Pierre, 2000, p. 504). In this way, I "I also tried to disassociate my identity, not looking for just one, but happy to find many-and no essence anywhere... A counterhistorian affirms her/his own knowledge as the perspective from which she/he operates, rejecting objectivity and her/his own erasure” (Chapman, 2005, p. 281).

believe autobiographical writing can be used as a Deleuzian simulacrum, a bad copy of (my)self, a way to interrupt the repetition of the self that resists becoming a treaty person, hesitant to attend treaty events, unable to truly connect the desire to have a deep relationship with this place to being a treaty person. Furthermore, as I focus on subjectivity related to treaty-person identity, I realize that these are accompanied by many more, here unnamed, selves. 
Inspired by Chapman (2005), I play with writing counter-historical, relationalautobiographical stories. Chapman (2005) might have called such stories "counter-memories” (p. 281). During autobiographical writing activities, there is an exploration of time, or space/place, as well as self/subjectivity. So, I wonder, "how does one think a subject not ordered by classical linear time-by past, present, and future-but produced within a folded, 'crumpled'... time so that time distant touches time near... both can be lived simultaneously?” (St. Pierre, 2004a, p. 332).

"Leroy Little Bear says there
are two kinds of time in the
Blackfoot language: The first
is the immediate present:
which has a two day limit:
there is today, yesterday and
the day before yesterday; or
today, tomorrow and the day
after. And then there is
everything else... the past and
the future are never more than
two days away" (Chambers,
2006, p. 31).

"Leroy Little Bear says there are two kinds of time in the Blackfoot language: The first is the immediate present: which has a two day limit: there is today, yesterday and the day before yesterday; or today, tomorrow and the day after. And then there is everything else... the past and the future are never more than 2006, p. 31).
It has been years since I wrote about the daffodils on my desk, since I began to try to communicate what I might want to do during my Ph.D. research. However, I imagine it began before that, and continues to begin, in a way that may not necessarily be conceptualized as only sequential. Autobiographical writing seems to blur time, and self, into something more than linear, with the past and future as part of the writing present, always in the middle of things. Instead, perhaps time is more like looking into the distance on the prairie, in many directions all at once, including the sky above and all around. There is no correct starting point, no complete perspective.

Yet, there are many ways in. Here and now and then and there, where I find myself, are all places to begin to explore (my)self as $I$, in its varied and tangled forms, subjectivity as relational processes. Relational, autobiographical counter-histories include elements of time, in unexpected ways it seems, to perhaps (re)produce myself as a White, woman, settler, but also with the possibility of being otherwise. For instance, without erasing the possibility for decolonization of the self. Chapman (2005) explains that “a counter-history isn't about recording smooth continuous movement, from then to now, via all the major political and economic events, instead it's about a 'profusion of entangled events... haphazard conflicts and the randomness of events’ (Foucault, 1984, pp. 88-89)” (p. 281). It encourages a complication of linearity, related to both time and subjectivity: thinking, writing, and becoming assemblages.

\section{Creating a Constellation}

I think of these assemblages as constellations of (un)thought. Briefly, I have alluded to constellational thinking, in the context of Jackson and Mazzei's (2012) plugging in of theory, a figuration they borrowed from Deleuze and Guattari. In their example, they plugged their interview data into particular philosophical
"Plugging in to produce something new is a constant, continuous process of making and unmaking. An assemblage isn't a thing-it is the process of making and unmaking the thing” (Jackson \& Mazzei, 2012, p. 1).

perspectives, conceptualized as Deleuzian thresholds, of Derrida, Spivak, Foucault, Butler, Deleuze, and, then, Barad. In doing so, Jackson and Mazzei (2012) "became aware of how theory and data constitute or make one another — and how, in the threshold, the divisions among and definitions of theory and data collapse" (p. 6). Furthermore, they explain a folding of "theory into data into theory”, and a folding of one's self into the research (p. 10), but also a folding back on itself and, in this case, on oneself. Interestingly, they stress that they "do not seek more and more reflexivity that reveals more and more about the researcher's ways of knowing. [Instead], 
we seek to unsettle the ' $\mathrm{I}$ ' of both the researcher and the researched who is a static and singular subject” (p. 10).

"We are doing and using the vocabulary and concepts as we push research and data and theory to its exhaustion in order to produce knowledge differently... we engage the threshold as a site of transformation” (Jackson \& Mazzei, 2012, p. 7).

engagement with: Derrida's notions of deconstruction, différance, and erasure; Foucault's care of the self; and, Deleuze's lines of flight, rhizome, and thresholds.

To explain how one might take up such a variety of philosophical theory to form a constellation, it is helpful to quote Lewis (2012) at length:

Concepts must be held together in a constellation that casts a light on that which is present precisely by its absence. Only in the assemblage of concepts as a constellation can we suddenly grasp in a fleeting flash the density, complexity, and centripetal force of the unspoken center which each register names and renames: history. The constellation does not collapse differences between concepts, nor does it simply valorize one conceptual model over the other. Rather they hang precariously together, maintaining an absent center. (p. 112)

Therefore, I attempt to form such life-assemblages, folded from my autobiographical writing and counter-stories as well as from laying the thinking-writing open to various philosophyconstituting selves/self/myself with further autobiographical writing, in an unsettling of Ifolding over and back and forward and sideways, again and again.

\section{Constellational Shapeshifting, of (My) Self}

Do I have the audacity to leap into the abyss of a constellation? Could I allow confusion, discomfort, and ambiguity to work against (my) self? Could I "shapeshift" like Raven and Coyote (O’Riley \& Cole, 2009)? This exploration of subjectivity—of a somewhat ecologically aware, treaty person who is unsure of naming herself as either-

"you know raven we've been part of the land and sky
and other scapes so long and so intimately
that we don't often think about our relationship to them-it-those ones
since them-it-those ones was/is us
and us was/is them-it-those ones” (O’Riley \& Cole, 2009, p. 125).
"coyote let's shapeshift let's split and so they did
into stones butterflies flowers ants and sunbeams moonshine
northern lights and tadpoles mosses and mushrooms and bear scat
sometimes they got stepped on sometimes eaten sometimes
but always they foundcreated a prism through which they were able to shapeshift
into something understandable
for those for whom reason is not the only guide” (O'Riley \& Cole, 2009, p. 131).
would be further troubled by stepping into Raven and Coyote's prism, if they would lend it to me. I ask tricksters to play in my constellation, towards unsettling this $I$ again and again. The settler in me wonders how I might come to be in ethical relation with them. How might I 
become-assemblage, a rhizome, by following their (lines of) flight. "Let's split... and so they did” (O’Riley \& Cole, 2009, p. 131).

While I continue to hesitate to lay it all out in a nice, sequential way, I have used self-

"The crumpled, folded time that cannot be measured and counted, the time in which concepts such as past, present, future are not thinkable, in which any time comes and goes, in which moments from any time in our lives may appear together...time is too thick” (St. Pierre, 2008, p.122). storied lines of flight to hint at how I envision inquiring about the trickiness of subjectivity-as-process. Leaning into discomfort, autobiographical, qualitative research moves beyond a straightforward activity. Becomingunsettled is partially a resistance of linearity, an interruption of the autonomous humanist self. (My)self conceptualized as tangled and mangled, as discursively constituted, is something other than a conscious, free

decision to shape shift. In partial ways, writing-the-self and writing counter-narratives-histories-memories of the yet unthought work to unsettle the mythical humanist self, that self that seems so normal and natural. Like St. Pierre, I "go home [and inward-outward] to do my homework, to

"For identity always gets away from us, it fractures, we lose it, and we don't know who we are, even at home” (St. Pierre, 2008, p. 120).

practice fieldwork and theory work and identity work" (St. Pierre, 2008, p. 123). Here and there, where time is thick, "for those for whom reason is not the only guide" (O’Riley \& Cole, 2009, p. 131), the tricksters are invited to come over to play, to tease me/us into becoming-unsettled, again and again and again. Gazing into the night sky, wondering at it - (my) self-hanging there, precariously together, shape shifting in the ruins of (my) self.

\section{Endnote}

${ }^{1}$ For the purposes of this discussion, I have chosen to take up a conversational tone and writing style to illustrate certain common sense assumptions of what it might mean to know oneself, as well as how these assumptions imply that knowledge of self (of identity) is made fully and without contention. 


\section{References}

Bingham, C. W. (2008). Derrida on teaching: The economy of erasure. Studies in Philosophy and Education, 27(1), 15-31.

Boler, M. (1999). Feeling power: Emotions and education. New York, NY: Routledge.

Britzman, D. P., \& Dippo, D. (2000). On the future of awful thoughts in teacher education. Teaching Education, 11(1), 31-37.

Chambers, C. M. (2006). “The land is the best teacher I ever had”: Places as pedagogy for precarious times. Journal of Curriculum Theorizing, 22(3), 27-38.

Chapman, V-L. (2005). Making a good Victoria sponge cake: Schooling Empire, class, gender and sexuality. International Journal of Qualitative Studies in Education, 18(3), 259-284.

Critchley, S. (1997). What is continental philosophy? International Journal of Philosophical Studies, 5(3), 347-363.

Davies, B. (2014). Legitimation in post-critical, post-realist times, or whether legitimation? In A. D. Reid, E. P. Hart, \& M. A. Peters (Eds.), A companion to research in education (pp. 443450). New York, NY: Springer.

Donald, D. T. (2009). Forts, curriculum and indigenous métissage: Imagining decolonization of Aboriginal-Canadian relations in educational contexts. First Nations Perspectives, 2(1), 124.

Donald, D. T. (2012). Indigenous métissage: A decolonizing research sensibility. International Journal of Qualitative Studies in Education, 25(5), 533-555.

Episkenew, J. (2009). Taking back our spirits: Indigenous literature, public policy, and healing (pp. 1-19). Winnipeg, MB: University of Manitoba Press.

Gough, N. (2009). Becoming transnational: Rhizosemiosis, complicated conversation, and curriculum inquiry. In M. McKenzie, P. Hart, H. Bai, \& B. Jickling (Eds.), Fields of green: Restorying culture, environment, and education (pp. 67-84). Creskill, NJ: Hampton.

Hasebe-Ludt, E., Chambers, C. M., \& Leggo, C. (2009). Life writing and literary métissage as an ethos for our times. New York, NY: Peter Lang.

Honan, E. (2007). Writing a rhizome: An (im)plausible methodology. International Journal of Qualitative Studies in Education, 20(5), 531-546.

Jackson, A. Y., \& Mazzei, L. (2012). Thinking with theory in qualitative research: Viewing data across multiple perspectives. London, UK: Routledge.

Laws, C. (2004). Poststructuralist writing at work. International Journal of Qualitative Studies in Education, 17(1), 113-127.

Lewis, T. E. (2012). Mapping the constellation of educational Marxism(s). Educational Philosophy and Theory, 44, 98-114. 
MacLure, M. (2011). Deconstruction as a method of research. In B. Somekh \& C. Lewin, (Eds.), Theory and methods in social research (2nd. ed.,pp. 286-289). London, UK: Sage.

Miller, J. L. (2005). Sounds of silence breaking: Women, autobiography, curriculum. New York, NY: Peter Lang.

Montgomery, K. (2013). Pedagogy and privilege: The challenges and possibilities of teaching critically about racism. Critical Education, 4(1), p. 1-21.

Newbery, L. (2012). Canoe pedagogy and colonial history: Exploring contested spaces of outdoor environmental education. Canadian Journal of Environmental Education, 17, 3045. Retrieved from http://cjee.lakeheadu.ca/index.php/cjee/article/view/1112/653

Office of the Treaty Commissioner. (2016). FAQs. Retrieved from http://www.otc.ca/faqs/1

O’Riley, P., \& Cole, P. (2009). Coyote and raven talk about the land/scapes. In M. McKenzie, P. Hart, H. Bai, \& B. Jickling (Eds.), Fields of green: Restorying culture, environment, and education (pp. 125-134). Creskill, NJ: Hampton.

Pillow, W. S. (2003). Confession, catharsis, or cure? Rethinking the uses of reflexivity as methodological power in qualitative research. International Journal of Qualitative Studies in Education, 16(2), 175-196.

Regan, P. (2010). Unsettling the settler within: Indian residential schools, truth telling, and reconciliation in Canada. Vancouver, BC: UBC Press.

Richardson, L. (2002). Skirting a pleated text: De-disciplining an academic life. In N. K. Denzin \& Y. S. Lincoln (Eds.), The qualitative inquiry reader (pp. 39-50). Thousand Oaks, CA: Sage.

Richardson, T. (2012). Between Native American and continental philosophy: A comparative approach to narrative and the emergence of responsible selves. Educational Philosophy and Theory, 44(6), 663-674.

St. Pierre, E. A. (1997). Circling the text: Nomadic writing practices. Qualitative Inquiry, 3, 403417.

St. Pierre, E. A. (2000). Poststructural feminism in education: An overview. International Journal of Qualitative Studies in Education, 13(5), 477-515.

St. Pierre, E. A. (2004a). Care of the self: The subject and freedom. In B. M. Baker \& K. E. Heyning (Eds.), Dangerous coagulations? The uses of Foucault in the study of education (pp. 325-358). New York, NY: Peter Lang.

St. Pierre, E. A. (2004b). Deleuzian concepts for education: The subject undone. Educational Philosophy and Theory, 36(3), 283-296.

St. Pierre, E. A. (2005). Writing: A method of inquiry. Part 2: Writing as a method of nomadic inquiry. In N. Denzin \& Y. Lincoln (Eds.), The Sage handbook of qualitative research (3rd ed., pp. 967-973). Thousand Oaks, CA: Sage. 
St. Pierre, E. A. (2008). Home as a site of theory: A fragment. International Review of Qualitative Research, 1(2), 119-124.

Stronach, I. (2011). From structuralism to post-structuralism. In B. Somekh \& C. Lewin, (Eds.), Theory and methods in social research (2nd ed., pp. 304-308). London, UK: Sage.

Thompson, G., \& Cook, I. (2013). The logics of good teaching in an audit culture: A Deleuzian analysis. Educational Philosophy and Theory, 45(3), 243-258.

Todd, S. (2007). Promoting a just education: Dilemmas of rights, freedom and justice. Educational Philosophy and Theory, 39(6), 592-603.

Tuck, E., \& Yang, K. W. (2012). Decolonization is not a metaphor. Decolonization: Indigeneity, Education, \& Society, 1(1), 1-40.

Tupper, J. A., \& Cappello, M. (2008). Teaching treaties as (un)usual narratives: Disrupting the curricular commonsense. Curriculum Inquiry, 35(5), 559-578.

Veracini, L. (2011). Introducing settler colonial studies. Settler Colonial Studies, 1(1), 1-12. doi:10.1080/2201473X.2011.10648799

West, D. (2010). Continental philosophy: An introduction (2nd ed., pp. 242-265) Malden, MA: Polity Press. 